\title{
Advances in the treatment of relapsing-remitting multiple sclerosis: the role of pegylated interferon $\beta$-la
}

This article was published in the following Dove Press journal:

Degenerative Neurological and Neuromuscular Disease

24 March 2017

Number of times this article has been viewed

\author{
Kendra L Furber ${ }^{1-3}$ \\ Marina Van Agten ${ }^{1-3}$ \\ Charity Evans ${ }^{2,4}$ \\ Azita Haddadi ${ }^{2}$ \\ J Ronald Doucette ${ }^{3-5, \dagger}$ \\ Adil J Nazarali ${ }^{1-4}$ \\ 'Laboratory of Molecular Cell \\ Biology, ${ }^{2}$ College of Pharmacy \\ and Nutrition, ${ }^{3}$ Neuroscience \\ Research Cluster, University of \\ Saskatchewan, ${ }^{4}$ Cameco Multiple \\ Sclerosis Neuroscience Research \\ Center, City Hospital, ${ }^{5}$ Department of \\ Anatomy and Cell Biology, College of \\ Medicine, University of Saskatchewan, \\ Saskatoon, SK, Canada
}

†Dr. J Ronald Doucette passed away on May I5, 2016
Correspondence: Adil J Nazarali GD30-I2, 107 Wiggins Road, Health Sciences Building, University of Saskatchewan, Saskatoon, SK, S7N 5E5, Canada

Tel +I 3069666334

Fax + I 3069666377

Email aj.nazarali@usask.ca
Abstract: Multiple sclerosis (MS) is a progressive, neurodegenerative disease with unpredictable phases of relapse and remission. The cause of MS is unknown, but the pathology is characterized by infiltration of auto-reactive immune cells into the central nervous system (CNS) resulting in widespread neuroinflammation and neurodegeneration. Immunomodulatory-based therapies emerged in the 1990s and have been a cornerstone of disease management ever since. Interferon $\beta$ (IFN $\beta$ ) was the first biologic approved after demonstrating decreased relapse rates, disease activity and progression of disability in clinical trials. However, frequent dosing schedules have limited patient acceptance for long-term therapy. Pegylation, the process by which molecules of polyethylene glycol are covalently linked to a compound, has been utilized to increase the halflife of IFN $\beta$ and decrease the frequency of administration required. To date, there has been one clinical trial evaluating the efficacy of pegylated IFN. The purpose of this article is to provide an overview of the role of IFN in the treatment of MS and evaluate the available evidence for pegylated IFN therapy in MS.

Keywords: interferon, pegylation, multiple sclerosis, relapsing-remitting, disease-modifying therapy

\section{Multiple sclerosis: an overview}

Multiple sclerosis (MS) is a progressive, neurodegenerative disease affecting roughly 2.3 million people worldwide. ${ }^{1} \mathrm{MS}$ is characterized by infiltration of auto-reactive T cells, $B$ cells and other immune mediators into the central nervous system (CNS), causing demyelinating lesions, axonal degeneration and formation of sclerotic plaques. ${ }^{2}$ Neural damage may manifest symptomatically as optic neuritis, numbness or tingling in the extremities, muscle weakness, slurred speech and bowel/bladder dysfunction. ${ }^{3-5}$ There is also an increasing appreciation of "soft" or "hidden" symptoms such as fatigue, ${ }^{6-8}$ cognitive impairment ${ }^{8-10}$ and comorbidity with other psychiatric disorders. ${ }^{11}$ Diagnosis typically occurs between 20 and 40 years of age but may occur at any stage in life, and women are affected two to three times more often than men. ${ }^{1}$ The etiology of MS remains unknown; however, it is likely an interplay between genetics and environmental factors. ${ }^{2,3,12-15}$

The first episode of neurological symptoms, characteristic of an inflammatory demyelinating event in the brain or spinal cord, is classified as a clinically isolated syndrome (CIS). ${ }^{16}$ This remains so until a definite diagnosis of MS, with "dissemination of demyelinating lesions in space and time", is made based on clinical episodes, magnetic resonance imaging (MRI) and/or analysis of cerebrospinal fluid. ${ }^{17,18}$ There are three subtypes of MS based on the manifestation of clinical symptoms: 
relapsing-remitting MS (RRMS), secondary progressive MS (SPMS) and primary progressive MS (PPMS), which can be further classified as active- or non-active based on clinical or MRI criteria. ${ }^{16}$ The most common diagnosis is RRMS, which affects $80-85 \%$ of patients and is characterized by acute exacerbations followed by periods of remission. ${ }^{1,5,19}$ Exacerbations, referred to as attacks or relapses, are defined as new symptoms in the absence of fever reflecting decreased neurological function, lasting at least $24 \mathrm{~h}$ and separated from other new symptoms by at least 30 days. ${ }^{18}$ Remission from relapse may be partial or complete; neurologic recovery following a relapse tends to be better in early stages of the disease but becomes less complete with repeated relapses. ${ }^{3,5}$ Approximately $75 \%$ of patients presenting with RRMS will convert to SPMS within 35 years of the initial symptoms, which is marked by a decline in acute relapses with a steady increase in the progression of disability. ${ }^{5}$ PPMS is diagnosed in $\sim 15 \%$ of cases and is characterized by a steady progression of disability from onset, which may occur with or without the presence of clinical relapses and/ or MRI activity. ${ }^{1,5,19}$

\section{Current therapies for disease management}

There are currently 11 disease-modifying therapies (DMTs) approved for MS in Canada (Table 1), with several emerging therapies in Phase II and III clinical trials. All currently approved DMTs modulate immune functions and are indicated for treatment of CIS, RRMS and/or SPMS with relapses. To date, there are no approved DMTs to mitigate neurodegenerative disease mechanisms for progressive forms of MS, although some experimental therapies are targeted toward neural repair mechanisms. First-line therapies in Canada include interferon beta-1b (IFN $\beta-1 b$; Betaseron ${ }^{\circledR}$, Extavia $^{\circledR}$ ), IFN $\beta-1 \mathrm{a}\left(\right.$ Avonex $^{\circledR}$, Rebif $\left.^{\circledR}\right)$, pegylated IFN $\beta-1 \mathrm{a}$ $\left(\right.$ PEG-IFN $\beta-1 \mathrm{a}$; Plegridy ${ }^{\circledR}$ ), glatiramer acetate (Copaxone $^{\circledR}$ ), teriflunomide (Aubagio ${ }^{\circledR}$ ) and dimethyl fumarate $\left(\right.$ Tecfidera $\left.^{\circledR}\right)$. Second-line therapies available are fingolimod (Gilenya ${ }^{\circledR}$ ), natalizumab (Tysabri ${ }^{\circledR}$ ) and alemtuzumab $\left(\right.$ Lemtrada $\left.^{\circledR}\right)$. Given that there is no cure for MS, the goals of current therapeutic interventions are to reduce the number and severity of relapses, minimize long-term disability and improve overall quality of life. In clinical trials, outcomes typically examined include annualized relapse rates (ARRs), MRI parameters such as disease burden (T2 lesion volume) or disease activity (number of new/newly enlarging $\mathrm{T} 2$ lesions or gadolinium-enhancing T1 lesions) and disability progression (Expanded Disability Status Scale [EDSS] ${ }^{20}$ ). The efficacy and safety profiles of currently available DMTs are briefly summarized in Table 1.

Overall, treatment decisions are based on benefit/risk profile. ${ }^{21}$ First-line therapies have shown similar efficacy in placebo-controlled ${ }^{22-30}$ and head-to-head trials, ${ }^{27,31-35}$ which is supported by recent meta-analysis data. ${ }^{36-38}$ Second-line therapies show greater efficacy in reducing relapse rates and MRI activity but are also associated with more adverse side effects and potential toxicities. ${ }^{39-43}$ These second-line therapies are typically used only in patients who show disease activity while on first-line therapies, who cannot tolerate first-line therapies or who have extremely active RRMS from onset. ${ }^{21}$ Thus, the optimization of MS therapy ultimately depends on individual disease activity, response to treatment, tolerability and practitioner or patient preference. Proven efficacy and long-term safety information from numerous clinical trials make IFN $\beta$ an attractive first-line therapy; however, an important drawback is patient adherence due to frequent dosing schedules. Thus, the development of pegylated IFN $^{44}$ (Plegridy ${ }^{\circledR}$ ) has provided an alternative injectable agent that has similar efficacy and safety profiles as traditional IFN $\beta$ therapies but significantly reduces the frequency of administration. ${ }^{44-50}$ In this review, we focus our discussion on placebo-controlled trials of subcutaneous IFN $\beta$ - $1 \mathrm{a}$ and head-to-head trials against other IFN $\beta$ formulations to evaluate the role of PEG-IFN $\beta$-1a therapy in MS (Table 2).

\section{Interferon $\beta$}

IFN $\beta$ was the first biologic approved for MS therapy. IFNs are a family of cytokines involved in the regulation of innate and adapted immunity ${ }^{12,51-53}$ and are thus ideal candidates for immunomodulatory therapies in MS. Early attempts at IFN therapy in MS included the use of IFN $\gamma$, IFN $\alpha$ and IFN $\beta .^{54}$ Unexpectedly, administration of IFN $\gamma$ resulted in activation of the immune system and increased the occurrence of relapses. Several different formulations of IFN $\alpha$ and IFN $\beta$ were explored with promising results, but IFN $\beta$ had a more acceptable patient safety profile. Both recombinant IFN $\beta$-1b produced in Escherichia coli and recombinant IFN $\beta$-1a produced in mammalian cells are approved for the treatment of MS (Table 1). Differences in post-translational modifications confer reduced biological activity of nonglycosylated IFN $\beta-1 b$ compared to glycosylated IFN $\beta-1 a^{55}$ which is reflected in their dosages. Clinical trials with IFN $\beta$ have demonstrated a reduction in relapse rates and MRI activity. ${ }^{22-24}$ Delays in disease progression, as measured with EDSS, have also been reported over the 1- to 2-year clinical 
Table I Disease Modifying Therapies approved by Health Canada for the treatment of Multiple Sclerosis ${ }^{\mathrm{a}}$

\begin{tabular}{|c|c|c|c|c|c|c|}
\hline DMT: Trademark & Indication & Dosage & Clinical Trial & Efficacy ${ }^{b}$ & Safety ${ }^{c, d}$ & Mechanism of Action \\
\hline \multicolumn{7}{|l|}{ First line } \\
\hline Interferon $\beta$-I b & $\mathrm{CIS}$ & & & & $\begin{array}{l}\text { Common to all } \\
\text { interferon } \beta\end{array}$ & Common to all interferon $\beta$ \\
\hline Betaseron $^{\circledR}$ & RRMS, & $250 \mu \mathrm{g}$ SC; QAD & IFN $\beta$ MSSG ${ }^{22}$ & $34 \%$ & - injection site rxn & - decrease in pro-inflammatory and increase \\
\hline Extavia $^{\circledR}$ & $\begin{array}{l}\text { SPMS w/ } \\
\text { relapses }\end{array}$ & $250 \mu g$ SC; QAD & & & $\begin{array}{l}\text { - flu-like symptoms } \\
\text { - decreased blood cell } \\
\text { counts }\end{array}$ & $\begin{array}{l}\text { anti-inflammatory cytokine profiles } \\
\text { - inhibition of ThI cell proliferation } \\
\text { - downregulation of antigen presentation by }\end{array}$ \\
\hline Interferon $\beta$-Ia & CIS, & & & & - increased LFT & B cells and glial cells in CNS \\
\hline Avonex ${ }^{\circledR}$ & RRMS, & $30 \mu \mathrm{gIM}$; QW & $\mathrm{MSCRG}^{23}$ & $18 \%$ & & - reduce entry of immune cells into the CNS \\
\hline \multirow[t]{2}{*}{ Rebif $^{\circledR}$} & SPMS w/ & $22 \mu \mathrm{g}$ SC; TIW & PRISMS $^{24}$ & $27 \%$ & & most likely through inhibition of MMPs \\
\hline & relapses & $44 \mu \mathrm{g}$ SC; TIW & PRISMS ${ }^{24}$ & $33 \%$ & & - increase expression of neurotrophic factors \\
\hline
\end{tabular}

PEG-Interferon $\boldsymbol{\beta}$ RRMS

Plegridy ${ }^{\otimes}$

\section{Glatiramer acetate \\ Copaxone $^{\circledR}$}

\section{CIS,
RRMS}

CMSSG $^{26} \quad 29 \%$

CONFIRM $^{27} \quad 29 \%$

Teriflunomide

Aubagio $^{\circledR}$

RRMS

14 mg PO; QD

TOWER ${ }^{29}$

$32 \%$

$36 \%$

Dimethyl fumarate
Tecfidera $^{\circledR}$

RRMS

$240 \mathrm{mg}$ PO; BD

DEFINE $^{28} \quad 53 \%$

CONFIRM $^{27} \quad 44 \%$

\section{Second line \\ Fingolimod \\ Gilenya $^{\circledR}$}

RRMS

$0.5 \mathrm{mg}$ PO; QD

FREEDOMS $^{40} \quad 54 \%$ FREEDOMS-II ${ }^{39} 48 \%$
$20 \mathrm{mg}$ SC; QD

$\begin{array}{ll}\text { - injection site rxn } & \text { - shifts from pro-inflammatory Th I/Th } 17 \text { to } \\ \text { - post-injection rxn } & \text { anti-inflammatory Th2 response } \\ \text { (flushing, chest pain, } & \text { - regulation of monocytes, dendritic \& B cells }\end{array}$

dyspnea) - increase expression of neurotrophic factors

- Gl symptoms _ - dihydroorotate dehydrogenase inhibitor;

- decreased blood cell reduces synthesis of pyrimidine nucleotides

counts $\quad-$ reduced proliferation of activated $\mathrm{T}$ cells

- increased LFT - shifts from pro-inflammatory ThI/ThI7 to anti-inflammatory Th2 response

- flushing - shifts from pro-inflammatory ThI/ThI7 to

- Gl symptoms anti-inflammatory Th2 response

- decreased blood cell - cytoprotective effects through Nrf2

counts - modulation of NF- $\mathrm{kB}$ activity

- strong allergic $r \times n$,

including anaphylaxis ${ }^{\mathrm{d}}$

- PML $^{d}$

- bradycardia - SIP receptor agonist; internalization and

- decreased blood cell degradation

counts $\quad-$ inhibits egress of activated lymphocytes

- infection from lymph node

- skin cancer $^{d} \quad-$ modulate astrocyte function

- PML $^{d}$

Natalizumab

Tysabri $^{\circledR}$

RRMS

300 mg IV; Q4W

AFFIRM $^{41}$

$68 \%$

- infusion rxn

- PML

- humanized mAb that binds $\alpha 4$ integrin

- blocks interaction with VCAM-I preventing migration of activated lymphocytes into CNS

Alemtuzumab Lemtrada $^{\circledR}$
$0.5 \mathrm{mg}$ IV;
5 consecutive days
in year I, then 3
consecutive days in
year 2

$$
\begin{array}{ll}
55 \% & - \text { infusion rxn } \\
49 \% & - \text { infection } \\
(\text { vs IFN } \beta \text {-I Ia) } & - \text { thyroid disorders } \\
& - \text { secondary } \\
& \text { autoimmunity }
\end{array}
$$

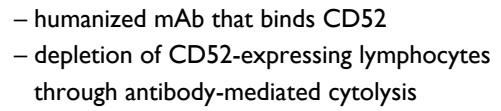

Notes: an additional DMT, daclizumab (humanized mAb that binds CD25) marketed as Zinbryta ${ }^{\circledR}$, was approved by Health Canada for treatment of RRMS in December 2016 while manuscript was in print; befficacy reported as \% reduction in relapse rate compared to placebo, except for alemtuzumab (compared to IFN $\beta$ - Ia), in Phase III clinical trials; ' reported in Phase III clinical trials, except indicated as ${ }^{d}$ recently reported by Health Canada (http://www.hc-sc.gc.ca; accessed January 14, 2017);42 eproposed mechanisms based on known pharmacology and/or current evidence from clinical trials and animal models. ${ }^{53}$

Abbreviations: BD, twice daily; CIS, clinically isolated syndrome; CNS, central nervous system; DMT, disease modifying therapy; Gl, gastrointestinal; IFN, interferon; IM intramuscular; IV, intravenous; LFT, liver function tests; mAb; monoclonal antibody; MMP, matrix metalloproteinase; MS, multiple sclerosis; NF- $\kappa \beta$, nuclear factor-kappa $\beta$; Nrf2, nuclear factor-erythroid 2-related factor 2; PEG, polyethylene glycol; PO, per oral; PML, progressive multifocal leukoencephalopathy; QAD, once every other day; $\mathrm{QD}$, once daily; QW, once weekly; Q2W, once every 2 weeks; Q4W, once every 4 weeks; RRMS, relapsing-remitting MS; rxn, reaction; SIP, sphingosine-I-phosphate; SC, subcutaneous; SPMS, secondary progressive MS; TIW, three times weekly; VCAM-I, vascular cell adhesion molecule I. 
Table 2 Summary of PRISMS, INCOMIN, EVIDENCE and ADVANCE trials

\begin{abstract}
PRISMS $^{24}$ - Prevention of Relapses and Disability by Interferon beta- I a Subcutaneously in Multiple Sclerosis
Inclusion criteria Clinically definite RRMS for $\geq 1$ year; $\geq 2$ relapses in preceding 2 years, and baseline EDSS scores of $0-5$

Exclusion criteria Previous systemic treatment with IFNs, lymphoid irradiation or cyclophosphamide or with other immunomodulatory or immunosuppressive therapy in previous 12 months

Intervention IFN $\beta$-la (Rebif $\left.{ }^{\circledast}\right) 22$ or $44 \mu \mathrm{g}$ SC TIW or placebo

Primary outcome Relapse rate over the course of 2-year study

Summary of Relapse rates were reduced by $27 \%$ in the $22 \mu \mathrm{g}$ IFN $\beta$-la intervention and $33 \%$ in the $44 \mu \mathrm{I}$ IFN $\beta$ - Ia intervention group compared to results placebo group. IFN $\beta$ - Ia interventions were also associated with an increased proportion of patients remaining relapse free, decreased change in EDSS scores and decreased time to first progression. MRI end points showed a decrease in total burden of disease ( $\Delta \mathrm{T} 2$ lesion volume), number of new/newly enlarging $\mathrm{T} 2$ lesions and number of TI Gd-enhancing lesions with IFN $\beta$ - I a treatment compared to placebo. High-dose treatment $(44 \mu \mathrm{g})$ showed more favorable outcomes compared to low-dose treatment $(22 \mu \mathrm{g})$
\end{abstract}

INCOMIN ${ }^{31}$ - Independent Comparison of Interferon

Inclusion criteria Clinically definite RRMS; $\geq 2$ clinically documented relapses during the preceding 2 years with no relapse (and no corticosteroid treatment) for at least 30 days before study entry and baseline EDSS score of I-3.5

Exclusion criteria Previous systemic treatment with IFN $\beta$ or treatment with other immunosuppressive or immunomodulatory drugs (except corticosteroids)

Intervention IFN $\beta$-Ib $\left(\right.$ Betaseron $\left.^{\circledR}\right) 250 \mu \mathrm{g}$ SC QAD or IFN $\beta$-Ia (Avonex $\left.{ }^{\circledR}\right) 30 \mu \mathrm{g} \mathrm{IM} \mathrm{QW}$

Primary outcome Proportion of patients who remained relapse free over the course of 2-year study

Summary of In the IFN $\beta$-Ib SC intervention group, $49 \%$ of patients remained relapse free compared to $33 \%$ in the IFN $\beta$ - Ia IM intervention results group. IFN $\beta$-Ib treatment was also associated with a decrease in ARR and 6-month sustained progression in EDSS. MRI end points showed an increase in the proportion of patients remaining free from new T2 lesions, remaining free from TI Gdenhancing lesions and showing no MRI activity with IFN $\beta$-Ib SC compared to IFN $\beta$ - I I IM treatment

EVIDENCE ${ }^{32}$ - Evidence of Interferon Dose-response-European North American Comparative Efficacy

Inclusion criteria Clinically confirmed RRMS; $\geq 2$ relapses in previous 2 years and baseline EDSS score of $0-5.5$

Exclusion criteria Previous treatment with IFN $\beta$

Intervention IFN $\beta$-Ia (Rebif $\left.{ }^{\circledR}\right) 44 \mu \mathrm{g}$ SC TIW or IFN $\beta$-Ia $\left(\right.$ Avonex $\left.^{\circledR}\right) 30 \mu \mathrm{g} \mathrm{IM} \mathrm{QW}$

Primary outcome Proportion of patients who remained relapse free at $\geq 48$ weeks

Summary of In the IFN $\beta$ - Ia SC TIW intervention group, $56 \%$ of patients remained relapse free compared to $48 \%$ in the IFN $\beta$ - Ia IM QW results intervention group. IFN $\beta$ - Ia SC TIW was also associated with a decrease in ARR and time to first relapse, but no difference was observed in EDSS progression. MRI end points showed a decrease in the number of new or enlarging T2 lesions in the IFN $\beta$ - Ia SC TIW compared to the IFN $\beta$ - I I IM QW treatment

ADVANCE ${ }^{25}$ - Pegylated Interferon beta-la for Relapsing-Remitting Multiple Sclerosis

Inclusion criteria RRMS; $\geq 2$ relapses in previous 3 years with at least one relapse in previous 12 months and baseline EDSS score of 0-5

Exclusion criteria Progressive MS, previous treatment with IFN $\beta$ for $>4$ weeks or discontinuation $<6$ months before baseline

Intervention PEG-IFN $\beta$ - Ia Plegridy ${ }^{\circledR}$ I25 $\mu \mathrm{g}$ SC Q2W or Q4W or placebo

Primary outcome ARR at 48 weeks

Summary of ARR were reduced by $36 \%$ in the PEG-IFN Q2W and $28 \%$ in the PEG-IFN Q4W intervention groups compared to the placebo results group. PEG-IFN $\beta$ interventions were also associated with an increased proportion of patients remaining relapse free and a decreased proportion of patients showing I2-week sustained EDSS progression. MRI end points showed a decrease in total burden of disease ( $\Delta \mathrm{T} 2$ lesion volume), number of new/newly enlarging $\mathrm{T} 2$ lesions and number of $\mathrm{TI}$ Gd-enhancing lesions with PEG-IFN $\beta$ treatment compared to placebo. More frequent injections (Q2W) showed more favorable outcomes compared to lowfrequency injections (Q4W)

Abbreviations: ARR, annualized relapse rate; EDSS, expanded disability status scale; IFN $\beta$, interferon beta; IM, intramuscular; MS, multiple sclerosis; PEG, polyethylene glycol; QAD, once every other day; QW, once weekly; Q2W, once every 2 weeks; Q4W, once every 4 weeks; RRMS, relapsing-remitting MS; MRI, magnetic resonance imaging; SC, subcutaneous; TIW, three times weekly.

trial periods, ${ }^{23,24}$ and long-term benefits have been associated with continued IFN $\beta$ treatment in follow-up studies. ${ }^{56,57}$ However, a large retrospective study by Shirani et a ${ }^{58}$ reported no link between IFN $\beta$ treatment and the long-term disability progression, which has renewed debate around this issue..$^{59-61}$

\section{Dosage and administration}

IFN treatment is currently indicated for the treatment of CIS, RRMS and SPMS with relapses. Commercially available formulations of IFN $\beta-1 b$ include Betaseron ${ }^{\circledR}$ and Extavia ${ }^{\circledR}$, which are administered subcutaneously (SC) every other day (QAD) at a dose of $250 \mu \mathrm{g}$. IFN $\beta-1 \mathrm{a}$ is marketed as Avonex ${ }^{\circledR}$ administered intramuscularly (IM) once weekly (QW) at a dose of $30 \mu \mathrm{g}$ or Rebif ${ }^{\circledR}$ administered SC three times weekly (TIW) at a dose of 22 or $44 \mu \mathrm{g}$.

\section{Mechanisms of action}

The precise mechanisms of action of IFN $\beta$ in MS therapy are unknown but have been attributed to its antiproliferative, antiviral and immunomodulatory abilities. ${ }^{52}$ Systemic 
administration of IFN $\beta$ is believed to primarily modulate immune cell function in the periphery. ${ }^{62}$ In general, IFN $\beta$ appears to oppose the pathogenic processes associated with MS disease progression by shifting from a pro-inflammatory to an anti-inflammatory immune profile (Figure 1). A key player in MS pathology are auto-reactive $\mathrm{T}$ cells that migrate across the blood-brain barrier (BBB), initiating inflammatory cascades in the CNS inflicting damage on axons, neurons and myelin sheaths. ${ }^{2,63}$ IFN $\beta$ therapy is associated with a decrease in the expansion of pro-inflammatory Th1 and Th17 subtypes and promotes the expansion of anti-inflammatory Th2 subtype ${ }^{64-68}$ IFN $\beta$ has also been shown to modulate the function of regulatory $\mathrm{T}$ cells,${ }^{69} \mathrm{~B}$ cells, ${ }^{70,71}$ natural killer cells ${ }^{72}$ and dendritic cells. ${ }^{73}$ The complexity of immune cell signaling networks makes it difficult to delineate the direct and indirect effects of IFN $\beta$ on each cell type.$^{52}$ Effects of IFN $\beta$ on $T$ cell function are mostly likely mediated indirectly through up-regulation of anti-inflammatory mediators, such as interleukin (IL)-10, ${ }^{66,74-78}$ and down-regulation of proinflammatory cytokines, such as IL-17, osteopontin and tumor necrosis factor $\alpha(\mathrm{TNF} \alpha),{ }^{64,73,74,78,79}$ secreted from other types of immune cells.

IFN $\beta$ has also been implicated in acting at the BBB, impeding migration of leukocytes into the CNS. Matrix metalloproteinases (MMPs), more specifically MMP-9 and tissue inhibitor of metalloproteinase-1 (TIMP-1), are involved in the degradation and remodeling of the extracellular matrix..$^{80}$ IFN $\beta$ has been shown to decrease serum levels
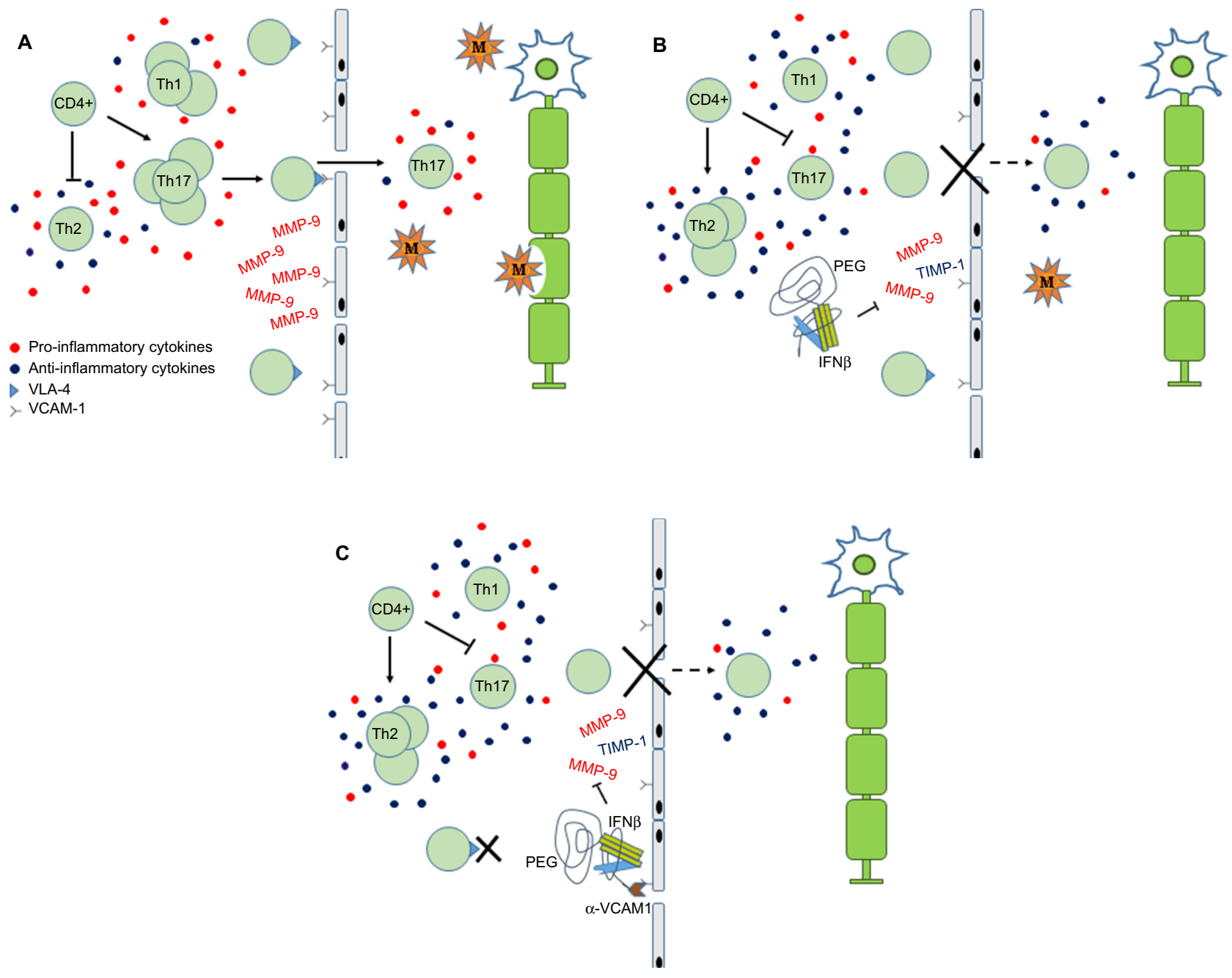

Figure I Schematic depicting the role of PEG-IFN $\beta$ therapy in MS.

Notes: (A) In MS, pro-inflammatory cytokines stimulate CD4+ cells to proliferate and differentiate into ThI and ThI7 effector cells. Activated T cells express VLA-4, which interacts with VCAM-I on endothelial cells, to facilitate crossing the BBB. In the CNS, auto-reactive T cells and macrophages result in damage to the myelin sheath, axons and neurons. Inflammatory demyelinating lesions result in the clinical presentation of MS. (B) IFN $\beta$ is conjugated to PEG to increase the molecule's serum concentration and half-life. Proposed actions of IFN $\beta$ include modulating cytokine milieu to favor anti-inflammatory pathways, which inhibits expansion of ThI/ThI7 and promotes expansion of Th2 cells. Down-regulation of VLA-4 and inhibition of MMP-9 reduce migration of activated T cells into CNS. (C) Linking of anti-VCAM-I antibodies to the PEG tail may enhance IFN $\beta$ anti-inflammatory actions by I) blocking interaction of leukocytes expressing VLA-4 with VCAM-I and 2) increasing local concentration of PEG-IFN $\beta$ at BBB. Abbreviations: BBB, blood-brain barrier; CNS, central nervous system; IFN $\beta$, interferon beta; $M$, macrophage; MMP, matrix metalloproteinase; MS, multiple sclerosis; PEG, polyethylene glycol; PEG-IFN $\beta$, pegylated interferon $\beta$; TIMP-I, tissue inhibitor of metalloproteinase-I; VCAM-I, vacular cell adhesion molecule I; VLA-4, very late activation antigen-4. 
of MMP-9 and modulate MMP-9:TIMP-1 ratio, and this was associated with a decrease in the number of new and/or active MRI lesions. ${ }^{81,82}$ To facilitate crossing the BBB, activated $\mathrm{T}$ cells up-regulate adhesion molecules, such as very late activation antigen-4 (VLA-4), which interact with vascular cell adhesion molecule 1 (VCAM-1) receptor expressed by endothelial cells (Figure 1). Evidence suggests that administration of IFN $\beta$ down-regulates expression of VLA-4/ $\alpha-4$ integrin, thereby inhibiting lymphocyte migration into the CNS. ${ }^{83-85}$ Together, these mechanisms reduce the number of pro-inflammatory immune cells in circulation and suppress the ability of activated leukocytes to enter the CNS. In addition to immunomodulatory effects, IFN $\beta$ treatment has been associated with increased expression of neurotrophic factors, ${ }^{86-88}$ which may convey cytoprotective effects.

\section{Clinical trials}

The Prevention of Relapses and Disability by Interferon beta-1a Subcutaneously in Multiple Sclerosis (PRISMS) study $^{23,89,90}$ was pivotal multi-centered, randomized, double-blind, placebo-controlled clinical trial investigating the benefit of SC IFN $\beta$-1a administration TIW for RRMS (Table 2). Participants were randomized to either 22 or $44 \mu \mathrm{g}$ or placebo groups with a primary outcome of number of relapses during the 2-year study period. ${ }^{23}$ The number of relapses was lower in both intervention groups compared to placebo: 27\% (95\% confidence interval [95\% CI] 14-39) reduction for the $22 \mu \mathrm{g}$ dose (1.82 vs 2.56$)$ and $33 \%$ (95\% CI 21-44) reduction for the $44 \mu \mathrm{g}$ dose (1.73 vs 2.56 ) (Table 3 ). This included a delay in the time to relapse and a decreased number of severe relapses, steroid courses and hospitalizations with IFN $\beta$-1 a treatment. Monitoring of disease activity with $\mathrm{MRI}^{89}$ showed a corresponding decrease in the number of Gd-enhancing T1 lesions, number of active T2 lesions and reduction in burden of disease (T2-weighted). Participants receiving placebo showed a $10.9 \%$ increase in total lesion volume compared to a $1.2 \%$ decrease for the $22 \mu \mathrm{g}$ intervention and $3.8 \%$ decrease for the $44 \mu \mathrm{g}$ intervention. After 4 years, IFN $\beta$ - 1 a treatment continued to reduce ARR ( 0.90 in year 1 vs 0.44 in year 4 for high-dose group) and improve MRI outcomes. ${ }^{90}$ Furthermore, both 4-year treatment groups showed favorable outcomes compared to the delaytreatment, crossover groups. Follow-up analyses at both $8^{91}$ and 15 years $^{56}$ are indicative of long-term benefit of IFN $\beta$-1a therapy on disease course, favoring early treatment intervention, higher dosages and longer exposure times.

Following the PRISMS study, head-to-head trials further investigated the efficacy of different IFN $\beta$ formulations and dosage in the Independent Comparison of Interferon
(INCOMIN) study ${ }^{31}$ and Evidence of Interferon Doseresponse-European North American Comparative Efficacy (EVIDENCE) study. ${ }^{32}$ The INCOMIN trial ${ }^{31}$ compared $250 \mu \mathrm{g}$ IFN $\beta$-1b SC injections QAD with $30 \mu \mathrm{g}$ IFN $\beta-1 \mathrm{a}$ IM injections QW over 2 years (Table 2). The primary outcome of the proportion of patients remaining relapse free favored IFN $\beta$-1b therapy (49\%) over IFN $\beta$-1a therapy (33\%); this was also reflected by a $29 \%$ reduction in the ARR ( 0.5 for IFN $\beta$-1b vs 0.7 for IFN $\beta$ - $1 \mathrm{a})$. For MRI outcomes, IFN $\beta$-1b SC therapy increased the proportion of patients who remained free from Gd-enhancing T1 lesions or new T2 lesions compared to IFN $\beta-1 \mathrm{a}$. The burden of disease for participants receiving IFN $\beta-1 \mathrm{~b}$ decreased $2.8 \%$ whereas IFN $\beta$-1a increased $11.7 \%$. However, due to multiple variables in treatment regimen, it is difficult to ascertain whether improved outcome relates to difference in formulation, dosage, frequency or route of administration.

The EVIDENCE trial ${ }^{32}$ compared IFN $\beta$-1a treatment at a dosage of $44 \mu \mathrm{g}$ administered by SC injections TIW (TIW) with a dosage of $30 \mu \mathrm{g}$ administered by IM injections QW over 1 year (Table 2). The primary outcome was the proportion of patients remaining relapse free, which favored $44 \mu \mathrm{g}$ SC TIW therapy (56\%) over $30 \mu \mathrm{g}$ IM QW therapy (48\%). There was a $17 \%$ reduction in ARR in the $44 \mu \mathrm{g}$ SC TIW group (0.54) compared to the $30 \mu \mathrm{g}$ IM QW group (0.65), and the mean number of active T2 lesions was also reduced by $36 \%$. Thus, both the IFN $\beta$-1b SC (cumulative dose $28 \mathrm{MIU} /$ week) in the INCOMIN study and the IFN $\beta$-1a SC (cumulative dose $36 \mathrm{MIU} /$ week) in the EVIDENCE trial showed greater efficacy than IFN $\beta$-1a IM (cumulative dose $6 \mathrm{MIU} /$ week). Pharmacokinetic studies indicate that the bioavailability of IFN $\beta$ does not appear to differ substantially between SC and IM administration. ${ }^{62}$ Taken together, data from the PRISMS, INCOMIN and EVIDENCE trials demonstrated that higher, more frequent dosing of IFN $\beta$ improve patient outcomes.

\section{Therapeutic considerations Safety profile}

IFNs are naturally occurring cytokines and generally well tolerated. The PRISMS study ${ }^{23}$ reported common adverse events of IFN $\beta$-1a treatment to include injection-site reactions (redness, swelling), flu-like symptoms, fever, headache and myalgia. However, flu-like symptoms were also commonly reported in placebo group (24\% vs $25 \%$ and $27 \%$ in 22 and $44 \mu \mathrm{g}$ treatment groups, respectively). Most injectionsite reactions were mild, with only eight incidences of skin necrosis (>150,000 injections). Less common, but serious, adverse events include decreased numbers of white blood cells and platelets and elevated liver enzymes. Similar safety 
Table 3 Comparison of currently available data on interferon $\beta$-Ia and pegylated interferon $\beta$-Ia

\begin{tabular}{|c|c|c|c|c|c|c|}
\hline \multirow[b]{2}{*}{ Administration } & \multicolumn{3}{|c|}{$\begin{array}{l}\text { IFNß-Ia } \\
\text { aPRISMS: 2-year study }{ }^{24}\end{array}$} & \multicolumn{3}{|c|}{$\begin{array}{l}\text { PEG-IFN } \beta \text {-Ia } \\
\text { aADVANCE: I-year study }{ }^{25}\end{array}$} \\
\hline & Placebo & $22 \mu \mathrm{g}$ & $44 \mu \mathrm{g}$ & Placebo SC; & $125 \mu \mathrm{g}$ & $125 \mu \mathrm{g}$ \\
\hline & SC; TIW & SC; TIW & SC; TIW & Q2W & SC; Q2W & SC; Q2W \\
\hline Number of patients enrolled & $187(170)$ & $189(167)$ & $184(165)$ & $500(456)$ & $512(438)$ & $500(438)$ \\
\hline$\%$ Completed treatment & 91 & 88 & 90 & 91 & 86 & 88 \\
\hline \multicolumn{7}{|l|}{ Clinical outcomes } \\
\hline Relapse rate ${ }^{b}$ & 2.56 & 1.82 & 1.73 & 0.40 & 0.26 & 0.29 \\
\hline $\begin{array}{l}\% \text { reduction of relapse } \\
\text { rate vs placebo }\end{array}$ & - & 27 & 33 & - & 36 & 28 \\
\hline \% relapse free (I year) & 22 & 37 & 45 & 71 & 81 & 78 \\
\hline Disability progression ${ }^{c}$ & 0.48 & 0.23 & 0.24 & 0.105 & 0.068 & 0.068 \\
\hline \multicolumn{7}{|l|}{ MRI outcomes } \\
\hline Burden of disease ${ }^{d}$ & $10.9 \%$ & $-1.2 \%$ & $-3.8 \%$ & $0.77 \mathrm{~cm}^{3}$ & $-0.26 \mathrm{~cm}^{3}$ & $0.06 \mathrm{~cm}^{3}$ \\
\hline T2 new/enlarging lesions & 4.5 & 1.3 & 0 & 10.9 & 3.6 & 7.9 \\
\hline TI Gd-enhancing lesions & 8.0 & 1.4 & 1.3 & 1.4 & 0.2 & 0.9 \\
\hline New active lesions ${ }^{e}$ & 10.6 & 2.1 & 1.3 & 11.2 & 3.7 & 7.3 \\
\hline NAbs & - & $\begin{array}{l}\text { Anti-IFN: } \\
23.8 \%\end{array}$ & $\begin{array}{l}\text { Anti-IFN: } \\
12.5 \%\end{array}$ & - & $\begin{array}{l}\text { Anti-IFN: }<1 \%^{f} \\
\text { anti-PEG: } 6 \%^{f}\end{array}$ & $\begin{array}{l}\text { Anti-IFN: }<1 \% \\
\text { anti-PEG: } 8 \%\end{array}$ \\
\hline \multicolumn{7}{|l|}{ Adverse events (\%)g } \\
\hline Injection-site reactions & 22 & 61 & 62 & 7 & 62 & 56 \\
\hline Influenza-like illness & 24 & 25 & 27 & 13 & 47 & 47 \\
\hline Headache & 44 & 47 & 45 & 33 & 44 & 41 \\
\hline Fatigue & 16 & 14 & 19 & 10 & 10 & 11 \\
\hline Myalgia & 8 & 13 & 14 & 6 & 19 & 19 \\
\hline Fever & 6 & 13 & 12 & 15 & 45 & 44 \\
\hline \multicolumn{7}{|l|}{ Abnormal blood cell counts } \\
\hline Leukopenia & 2 & 4 & 8 & 1 & 7 & 4 \\
\hline Lymphopenia & 4 & 5 & 13 & 3 & 5 & 4 \\
\hline \multicolumn{7}{|l|}{ Elevated liver enzymes } \\
\hline $\begin{array}{l}\text { Alanine } \\
\text { aminotransferase }\end{array}$ & 1 & 5 & 7 & 1 & 2 & 2 \\
\hline $\begin{array}{l}\text { Aspartate } \\
\text { aminotransferase }\end{array}$ & 1 & 2 & 3 & 1 & 1 & 1 \\
\hline $\begin{array}{l}\text { Adverse events resulting } \\
\text { in discontinuation }\end{array}$ & 1 & 3 & 5 & 1 & 5 & 5 \\
\hline \multicolumn{7}{|l|}{ Pharmacokinetics ${ }^{62}$} \\
\hline$A \cup C^{h}$ & - & $12 \mathrm{IU} \cdot \mathrm{h} / \mathrm{mL}$ & $71.6 \mathrm{IU} \cdot \mathrm{h} / \mathrm{mL}$ & - & $24.5 \mathrm{ng} \cdot \mathrm{h} / \mathrm{mL}$ & $23.5 \mathrm{ng} \cdot \mathrm{h} / \mathrm{mL}$ \\
\hline$C_{\max }$ & - & $1.3 \mathrm{IU} / \mathrm{mL}$ & $12.8 \mathrm{IU} / \mathrm{mL}$ & - & $221 \mathrm{pg} / \mathrm{mL}$ & $202 \mathrm{pg} / \mathrm{mL}$ \\
\hline $\mathrm{T}_{\max }^{\max }(\mathrm{h})$ & - & $1-2$ & 0.25 & - & 35.9 & 35.1 \\
\hline half-life $(h)$ & - & n.a. & 12.8 & - & 62.8 & 56.8 \\
\hline
\end{tabular}

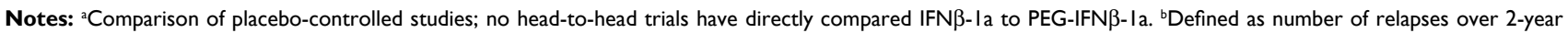
study period (PRISMS) or ARR at 48 weeks (ADVANCE). 'Defined as change in EDSS over duration of study (PRISMS) or proportion of patients with I2-week sustained

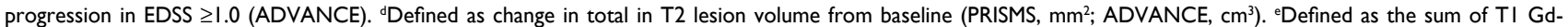
enhancing and new or newly enlarging T2 lesions (PRISMS, clinically unique; ADVANCE new active). 'Reported at 2 years. ${ }^{122}$ sPRISMS reported adverse events in first 3 months of therapy and ADVANCE reported adverse events over the full 48 weeks. hMeasured over $8 \mathrm{~h}$ for $22 \mu \mathrm{g}$ IFN $\beta$ - I a and measured over $168 \mathrm{~h}$ for $44 \mu \mathrm{g}$ IFN $\beta$ - Ia and I $25 \mu \mathrm{g}$ PEG-IFN $\beta$ - Ia. $C_{\text {max }}$, maximum serum concentration; $T_{\text {max }}$, time to reach $C_{\text {max }}$.

Abbreviations: ARR, annualized relapse rate; AUC, area under curve; EDSS, Expanded Disability Status Scale; IFN, interferon; Q2W, once every 2 weeks; MRI, magnetic resonance imaging; n.a., not available; NAbs, neutralizing antibodies; PEG, polyethylene glycol; SC, subcutaneous; TIW, three times weekly.

profiles were reported in 4-year follow-up studies. Over 4 years, there were three deaths reported none of which were related to the treatment. ${ }^{90,92}$

There were initially reports of IFN $\beta$ therapy causing an increase in the incidence of depression. Given the neurologic pathology of MS and its chronic progressive nature, the estimated lifetime prevalence of major depression in MS is as high as $50 \% .{ }^{93,94}$ With such a high comorbidity rate of depression among MS patients, ${ }^{11}$ it is difficult to definitively link IFN $\beta$ therapy with an increased risk of depression. There was no significant difference among treatment groups in the PRISMS trial; depression was reported by $28 \%$ of patients receiving placebo, $21 \%$ of patients receiving $22 \mu \mathrm{g}$ of IFN $\beta$ and $24 \%$ of patients receiving $44 \mu \mathrm{g}$ of IFN $\beta .{ }^{23}$ During the study, one patient in the placebo group committed suicide and three patients in each group reported attempting suicide or 
suicidal ideation. Furthermore, no difference in the incidence of depression has been found between patients receiving IFN $\beta$ and glatiramer acetate therapy. ${ }^{95}$

\section{Neutralizing antibodies}

Another concern associated with IFN $\beta$-1a therapy is the production of neutralizing antibodies (NAbs). In the PRISMS study, $23.8 \%$ of participants receiving the $22 \mu \mathrm{g}$ dose and $12.5 \%$ of participants receiving the $44 \mu \mathrm{g}$ dose were positive for NAbs but concluded that NAbs had no impact on the mean relapse count in either intervention. ${ }^{23}$ The INCOMIN study reported more frequent production of NAbs with IFN $\beta-1 b(30 \%)$ than with IFN $\beta-1 \mathrm{a}(7 \%)$ therapy, but again this did not appear to negatively impact treatment efficacy. ${ }^{31}$ In contrast, the EVIDENCE study with IFN $\beta$-1a reported a higher prevalence of NAbs within the $44 \mu \mathrm{g}$ SC TIW (26\%) compared to the $30 \mu \mathrm{g}$ IM QW (3\%) intervention and noted that NAbs developed earlier among the high-dose intervention. ${ }^{32}$ Disease activity was significantly greater in participants receiving $44 \mu \mathrm{g}$ SC TIW who were positive for NAbs compared to those who were negative for NAbs; however, $\mathrm{NAb}^{+\mathrm{ve}}$ and $\mathrm{NAb} b^{-\mathrm{ve}}$ participants had less MRI activity than their $30 \mu \mathrm{g}$ IM QW counterparts.

The clinical implications of NAbs in IFN $\beta$ therapy remain unclear. High titers of NAbs appear to be related to the formulation, dosing regimen and route of administration. ${ }^{31,32,96-98}$ NAb levels often peak within 6-12 months of starting therapy and then decline, with $\sim 10 \%$ of patients developing persistent NAbs. ${ }^{98}$ At persistently high titers, NAbs can reduce biological activity ${ }^{99,100}$ and negatively impact long-term drug therapy ${ }^{97,99,101-103}$ The most recent treatment recommendations provide little consensus on how to approach this issue: ${ }^{21}$ current practices include periodic testing of NAb levels, testing for NAbs only when considering switching therapies or opting to base treatment decisions solely on clinical outcomes.

\section{Adherence}

Frequent IFN $\beta$ administration has been shown more effective for managing RRMS; ${ }^{31,32}$ however, given that the disease is chronic and progressive, this dosing regimen may not be amenable for many patients. Overall, adherence rates of injectable DMTs requiring frequent administration (i.e., $\geq \mathrm{QW}$ ) have been estimated at $27-76 \%,{ }^{104-110}$ with decreased adherence associated with an increased risk of relapse. ${ }^{105,106}$ The most commonly reported reasons for discontinuation were lack of efficacy, tolerability (i.e., adverse effects such as flu-like symptoms and injection-site reactions) and patients' decision (i.e., both practical issues and mental exhaustion). ${ }^{11-115}$ Discontinuation due to adverse effects typically occurs within the first year of treatment, ${ }^{114,115}$ but this can be mitigated by dose titration, prophylactic treatment of flu-like symptoms and injection-site reactions, increased patient education and the use of autoinjectors. ${ }^{16,117}$ Another viable approach has been drug modification to increase pharmacokinetic profile and prolong bioavailability to reduce frequency of administration, such as the pegylation of IFN $\beta-1 \mathrm{a} .{ }^{44}$

\section{Pegylated interferon $\beta$}

Pegylation is the process by which molecules of polyethylene glycol (PEG) are chemically conjugated to a biological product. The addition of PEG increases the size of a macromolecule, generally increasing its solubility, stability and mobility in solution. ${ }^{118,119}$ Pegylation decreases the rate of renal clearance and may also reduce receptor- or antibodymediated clearance and proteolytic degradation. ${ }^{44,118}$ This results in increased exposure, half-life and serum concentrations of the therapeutic agent. Other potential benefits of pegylation are reduced antigenicity and immunogenicity, as PEG could potentially mask recognition of epitopes. ${ }^{44,118}$ Addition of large PEG molecules can often decrease binding to target through steric hindrance, ${ }^{119}$ yet the overall goal is to balance pharmacodynamic and pharmacokinetic properties to improve treatment efficacy. ${ }^{118}$ These attributes are ideal for a biomolecule such as IFNs, which are rapidly cleared without any modifications. ${ }^{62}$ For example, pegylated forms of IFNo-2a (Pegasys ${ }^{\circledR}$; Hoffman La Roche) and IFN $\alpha-2 b$ (PegIntron ${ }^{\circledR}$; Schering-Plough) have been used in the management of chronic hepatitis $\mathrm{C}$ for over a decade. ${ }^{119,120}$ The development of PEG-IFN $\beta$-1a, a $20 \mathrm{kDa}$ linear methoxy PEG molecule conjugated to the alpha amino group of the $\mathrm{N}$ terminal amino acid residue of IFN $\beta$, demonstrated a desirable pharmacokinetic and pharmacodynamic profile to decrease the frequency of administration for the management of MS. ${ }^{44}$

\section{Dosage and administration}

PEG-IFN $\beta-1 \mathrm{a}$ is marketed as Plegridy ${ }^{\circledR}$ and currently indicated for the treatment of RRMS. PEG-IFN $\beta$ - $1 \mathrm{a}$ is administered SC every 2 weeks (Q2W) at a dose of $125 \mu \mathrm{g}$.

\section{Mechanisms of action}

The mechanisms of action of PEG-IFN $\beta$ - 1 a are presumably similar to its parent compound. The N-terminus of IFN $\beta$, which is known not to be critical for its activity, was chosen for the site of attachment. ${ }^{44}$ Although predicted not to affect ligand-binding interactions, a size-dependent decrease in antiviral activity was observed with increasing size of PEG molecules. As smaller PEG molecules did not convey the desired pharmacokinetic properties, $20 \mathrm{kDa}$ was 
chosen for the pegylation of IFN $\beta-1 \mathrm{a} .{ }^{44}$ In healthy controls, PEG-IFN $\beta$-1a and IFN $\beta$ - $1 \mathrm{a}$ administration resulted in similar changes in cytokine gene expression favoring an anti-inflammatory profile. ${ }^{121}$ To our knowledge, the antiinflammatory properties of PEG-IFN $\beta$-1a have not yet been directly investigated or reported in clinical trials or animal models of MS.

\section{Clinical trials}

To date, there has been one randomized, double-blind, placebo-controlled clinical trial investigating PEG-IFN $\beta$-1a in RRMS. The ADVANCE trial25,122,123 was a 2-year study, consisting of a 48 -week placebo-controlled phase and 48 -week crossover phase, comparing the efficacy of $125 \mu \mathrm{g}$ PEG-IFN $\beta$-1a administered by SC injection Q2W or every 4 weeks (Q4W; Table 2). At 48 weeks, the primary outcome of ARRs showed a benefit for both PEG-IFN $\beta$ therapy regimens compared to placebo. ${ }^{25}$ The ARRs were $0.256(95 \% \mathrm{CI}$ 0.206-0.318) for the Q2W intervention and 0.288 (95\% CI 0.234-0.355) for the Q4W intervention compared to 0.397 for placebo (95\% CI $0.328-0.481$ ), corresponding to a $36 \%$ and $28 \%$ reduction in the $\mathrm{Q} 2 \mathrm{~W}$ and $\mathrm{Q} 4 \mathrm{~W}$, respectively. MRI outcomes $^{25,123}$ showed a decrease in the number of new or newly enlarging T2 lesions in both PEG-IFN $\beta$ treatment groups but only a significant decrease in the number of Gdenhancing and T1 hypointense lesions in the Q2W group compared to placebo. Total T2 lesion volume increased in the placebo group by $0.77 \mathrm{~cm}^{3}$ and Q4W treatment group by $0.06 \mathrm{~cm}^{3}$ and decreased in the Q2W treatment group by $0.26 \mathrm{~cm}^{3}$. The proportion of patients achieving "no evidence of disease activity" (NEDA), defined as absence of both clinical and MRI disease activity, was $33.9 \%$ in the PEGIFN $\beta$ Q2W, 21.5\% in the PEG-IFN $\beta$ Q4W and 15.1\% in the placebo group. ${ }^{123}$ These data demonstrate a benefit of both PEG-IFN $\beta$ treatments but suggest an advantage of a more frequent dosing regimen to minimize disease activity.

Upon completion of the first year, participants receiving placebo were re-randomized to one of the treatment interventions and participants already receiving drug intervention remained on the same dosing regimen. ${ }^{122}$ Both continuous intervention groups showed a reduction in the ARR compared to the corresponding delayed-treatment groups, 37\% reduction and $17 \%$ reduction in the $\mathrm{Q} 2 \mathrm{~W}$ and $\mathrm{Q} 4 \mathrm{~W}$ dosing, respectively. The ARR decreased among participants receiving continuous PEG-IFN $\beta$ Q2W from 0.230 (95\% CI 0.183-0.291) to 0.178 (95\% CI 0.136-0.233), while the ARR was roughly maintained among participants receiving continuous PEG-IFN $\beta$ Q4W (0.286 [95\% CI 0.231-0.355] and 0.291 [95\% CI $0.231-0.368]$ ). Also, the number of new or newly enlarging T2 lesions continued to decline for both the continuous Q2W and Q4W groups. When directly comparing the two dosing regimens, there was a $24 \%$ reduction in ARR and $60 \%$ reduction in the number of new or newly enhancing T2 lesions in the Q2W compared to the Q4W. Subgroup analysis indicated that the efficacy of PEG-IFN $\beta$ was similar across different populations of RRMS patients. ${ }^{124} \mathrm{~A}$ recent preliminary report from the ATTAIN study, an extension of the ADVANCE trial, indicates that the efficacy of each treatment was maintained over 3 years. ${ }^{45}$ This suggests, similar to other IFN $\beta$ formulations, that early intervention, higher cumulative dosage and increased exposure time are advantageous.

\section{Therapeutic considerations Safety profile}

Reported side effects of PEG-IFN $\beta$ were similar to those previously reported for both SC and IM injections of IFN $\beta$. These included mild-to-moderate adverse events such as injection-site reactions, influenza-like illness, fever, chills, headache and myalgia. In year 1 , the incidence of discontinuation of the study due to adverse events was $6 \%$ in both treatment groups and $1 \%$ in the placebo group, the most commonly reported reason being influenza-like illness. The rate of severe adverse events was similar among the three study groups: $11 \%$ in the placebo, $18 \%$ for the every 2 -week intervention and $16 \%$ for the every 4 -week intervention. ${ }^{25}$ Participants in both intervention groups had decreased number of blood cells and elevated liver enzymes, but neither was determined to be clinically significant and the majority returned to normal ranges within 2 years. The incidence of abnormal white blood cell counts remained low $(\leq 10 \%$ of participants) across both intervention groups. ${ }^{25,122}$ Over the 2-year study, nine deaths occurred; however, an independent safety-monitoring board reported that these events were not likely related to the study drug and did not change the riskbenefit profile of PEG-IFN. ${ }^{122}$ A 3-year follow-up from the ATTAIN study indicates that PEG-IFN continues to show a similar safety profile. ${ }^{125}$ As with other pegylated pharmaceuticals, adverse side effects are associated primarily with the active drug not the PEG moiety. ${ }^{119}$

\section{Neutralizing antibodies}

As stated previously, traditional SC IFN $\beta$-1a therapy can result in persistently high levels of NAbs ( $\sim 10 \%$ of patients), which may negatively impact the treatment efficacy. Development of IFN $\beta$ antibodies was $<1 \%$ in both interventions, whereas development of antibodies against PEG was reported at 6\% in Q2W and 8\% in Q4W interventions. ${ }^{122}$ The appearance of NAbs was determined not to impact efficacy or safety 
of treatment, but due to low rate of incidence in this study, data should be interpreted with caution. ${ }^{126}$

\section{Adherence}

The use of PEG-IFN $\beta$ - 1 a has been estimated to reduce the number of injections by $>90 \%$ compared to other first-line therapies. ${ }^{37}$ In the ADVANCE study, $88 \%$ of the participants completed the first year ${ }^{25}$ and $90 \%$ of continuing patients completed the second year. ${ }^{122}$ Tolerability and adverse events, such as flu-like symptoms and injection-site reactions, were still major factors leading to discontinuation; however, management strategies similar to standard IFN therapies can be used to mitigate impact. ${ }^{127}$ Adherence to treatment, defined by the number of doses received divided by the number of doses expected to receive, was $>99 \%$ in each group. ${ }^{25}$ It should be noted though that adherence in controlled trials is usually greater than in a clinical setting. ${ }^{116}$ While reduced frequency of administration is expected to increase adherence, ${ }^{44,45,47,49}$ this will need to be further evaluated as PEG-IFN therapy is integrated into clinical practice.

\section{Interferon $\beta$ versus pegylated interferon $\beta$}

A comparison of the efficacy, safety profile and pharmacokinetics data for PEG-IFN $\beta$ - 1 a and its parent compound IFN $\beta-1 \mathrm{a}$ is reported in Table 3 . A considerable amount of data are available regarding the pharmacokinetic properties of different IFN $\beta$ formulations, dosages and routes of administration; the only factor that substantially alters the pharmacokinetic profile is pegylation. ${ }^{62} \mathrm{PEG}$-IFN $\beta$-1 a administration by IM injection showed a fourfold increase in drug exposure, assessed by the area under the curve (AUC), compared to an equal dosage of IFN $\beta$ - 1 a. ${ }^{121}$ PEG-IFN $\beta$ and IFN $\beta$ administration both resulted in altered cytokine expression profiles, but the pharmacological response with PEG-IFN $\beta$ had a more rapid onset and was sustained for a longer period. ${ }^{121}$ Only one study has done a direct comparison between standard therapeutic doses of IFN $\beta$ - $1 \mathrm{a}$ and PEG-IFN $\beta$ - $1 \mathrm{a}$ administered by SC injection over the course of 2 weeks. ${ }^{128}$ When healthy participants were evaluated for accumulative drug exposure with six doses of $44 \mu \mathrm{g}$ IFN $\beta$-1a SC compared to a single dose of $125 \mu \mathrm{g}$ PEG-IFN $\beta$ - $1 \mathrm{a}$, the AUC was found to be $60 \%$ higher for the PEG-IFN $\beta$ dosage regime. This corresponds to approximately fourfold increase in $\mathrm{C}_{\max }$, approximately sixfold increase in $\mathrm{T}_{\max }$ and approximately twofold increase in half-life. Thus, pegylation of the IFN $\beta$-1 a molecule results in an increased serum concentration and greater drug exposure compared to the traditional IFN $\beta$-1a therapy. The tolerability of PEG-IFN $\beta$ was favorable with a lower incidence of adverse events compared to the IFN $\beta$ dosing regimen. ${ }^{128}$ This was presumably due to the need for less frequent injections with PEG-IFN $\beta$.

To date, there are no published head-to-head clinical trials comparing PEG-IFN $\beta$ to the alternative formulations of IFN $\beta$ or any other DMT. In the PRISMS study ${ }^{23}$ and the ADVANCE study, ${ }^{25}$ similar efficacy was observed between IFN $\beta$ - $1 \mathrm{a}$ and PEG-IFN $\beta$ - $1 \mathrm{a}$ interventions when comparing \% relative reduction in relapse rate. Both studies also reported favorable MRI outcomes, including a decrease in disease activity (T1- and/or T2-weighted) and burden of disease (total lesion volume) with treatment. However, due to different methodology and reporting measures, direct comparisons of study outcomes are difficult. Although meta-analysis of efficacy and safety profiles ${ }^{37}$ and cost-effectiveness analysis ${ }^{129}$ tend to favor PEG-IFN $\beta$-1a, these are relatively premature. Full results from the ATTAIN study will provide further data on the long-term efficacy on safety of PEG-IFN $\beta$ therapy. In addition to clinical trial data, longitudinal studies with IFN $\beta$-1 a treatment also suggest positive effects on cognitive function ${ }^{130-132}$ and long-term benefits of disease progression, ${ }^{55,90}$ but these types of data sets are not yet available for PEG-IFN $\beta$-1a. Ultimately, head-to-head clinical trials and observational studies from clinical practice will continue to inform us about the role of PEG-IFN $\beta$ in MS disease management.

\section{What are future therapeutic possibilities for PEG-IFN?}

The conjugation of PEG to IFN $\beta$ - 1 a has expanded the therapeutic options for the management of MS. By prolonging the half-life of IFN $\beta$-1a, increasing its exposure and decreasing its elimination, ${ }^{44,62}$ this novel formulation provides a safe and effective first-line therapy with a decreased frequency of administration. This new PEG-IFN $\beta$ formulation has also created a platform upon which other immunomodulatory molecules may be added (Figure 1). This may serve to enhance the efficacy of IFN $\beta$ by 1 ) providing opportunity to develop combination therapies and 2) targeting the IFN $\beta$ to specific locations within the body. For example, by specifically targeting VCAM-1, expressed on activated endothelial cells, the anti-VCAM-PEG-IFN molecule could more effectively block activated $\mathrm{T}$ cells from crossing the BBB. Theoretically, this would also increase the local concentration of IFN $\beta$ to the BBB possibly directing its immunomodulatory effects to this compartment and reduce non-specific systemic effects. Whether these hypothetical modifications would enhance IFN activity has yet to be determined. However, if successful it may lead to targeted delivery of IFN $\beta$ with 
potentially greater efficacy and a reduction in frequency of side effects.

\section{Conclusion}

IFN $\beta$, a naturally occurring cytokine, was the first DMT approved for MS therapy. Clinical evidence has consistently demonstrated a decrease in relapse rates and MRI activity; however, the inherent physical properties require it to be frequently administered in order to maintain therapeutic concentrations. The conjugation of PEG molecules to IFN $\beta$ alters the pharmacokinetic properties of the parent drug, thereby decreasing the frequency of administration. This also provides a novel platform for combination therapy approach.

ADVANCE is currently the only clinical trial with published results on the efficacy of PEG-IFN $\beta$-1 a compared to placebo in the treatment of RRMS; to date, there are no headto-head trials comparing PEG-IFN $\beta-1$ a to other approved DMTs. Furthermore, there are no treatment guidelines for practitioners that include initiating or switching to PEG-IFN $\beta$ therapy. Here, we have made an effort to compile currently available information regarding IFN $\beta$ therapy options with respect to various formulations. All available data suggest that the efficacy and safety profile of PEG-IFN $\beta$ - $1 \mathrm{a}$ is comparable to other IFN $\beta$ therapies, with the added benefit of a decreased dosing schedule. This provides patients and practitioners with a viable alternate first-line therapy in the treatment of MS.

\section{Acknowledgments}

Funding from Canadian Institutes of Health Research, Saskatchewan Health Research Foundation and Natural Sciences and Engineering Research Council of Canada is gratefully acknowledged. KLF is supported by the endMS Postdoctoral Fellowship from the Multiple Sclerosis Society of Canada. We thank Dr. Katherine Knox for review of an earlier draft of the manuscript. This manuscript is dedicated to our colleague Dr. J. Ronald Doucette who passed away last year.

\section{Disclosure}

The authors report no conflicts of interest in this work.

\section{References}

1. Multiple Sclerosis International Federation (MSIF) [homepage on the Internet]. Atlas of MS: Mapping Multiple Sclerosis Around the World. 2013. Available from: www.msif.org/atlas. Accessed January 14, 2017.

2. Dendrou CA, Fugger L, Friese MA. Immunopathology of multiple sclerosis. Nat Rev Immunol. 2015;15(9):545-558.

3. Compston A, Coles A. Multiple sclerosis. Lancet. 2008;372(9648): $1502-1517$

4. Lipsy RJ, Schapiro RT, Prostko CR. Current and future directions in MS management: key considerations for managed care pharmacists. J Manag Care Pharm. 2009;15(9 suppl A):S2-S15. quiz S16-7.
5. Coles A. Multiple sclerosis. Pract Neurol. 2009;9(2):118-126.

6. Induruwa I, Constantinescu CS, Gran B. Fatigue in multiple sclerosis - a brief review. J Neurol Sci. 2012;323(1-2):9-15.

7. Chalah MA, Riachi N, Ahdab R, Creange A, Lefaucheur JP, Ayache SS. Fatigue in multiple sclerosis: neural correlates and the role of non-invasive brain stimulation. Front Cell Neurosci. 2015;9:460.

8. Penner IK. Evaluation of cognition and fatigue in multiple sclerosis: daily practice and future directions. Acta Neurol Scand. 2016;134(suppl 200): 19-23.

9. Rao SM, Leo GJ, Bernardin L, Unverzagt F. Cognitive dysfunction in multiple sclerosis. I. frequency, patterns, and prediction. Neurology. 1991;41(5):685-691.

10. Rocca MA, Amato MP, De Stefano N, et al. Clinical and imaging assessment of cognitive dysfunction in multiple sclerosis. Lancet Neurol. 2015;14(3):302-317.

11. Marrie RA, Reingold S, Cohen J, et al. The incidence and prevalence of psychiatric disorders in multiple sclerosis: a systematic review. Mult Scler. 2015;21(3):305-317.

12. Annibali V, Mechelli R, Romano S, et al. IFN-beta and multiple sclerosis: from etiology to therapy and back. Cytokine Growth Factor Rev. 2015;26(2):221-228.

13. Ebers G. Interactions of environment and genes in multiple sclerosis. J Neurol Sci. 2013;334(1-2):161-163.

14. Golan D, Staun-Ram E, Miller A. Shifting paradigms in multiple sclerosis: from disease-specific, through population-specific toward patient-specific. Curr Opin Neurol. 2016;29(3):354-361.

15. Carlson RJ, Doucette JR, Knox K, Nazarali AJ. Pharmacogenomics of interferon-beta in multiple sclerosis: what has been accomplished and how can we ensure future progress? Cytokine Growth Factor Rev. 2015;26(2):249-261.

16. Lublin FD, Reingold SC, Cohen JA, et al. Defining the clinical course of multiple sclerosis: the 2013 revisions. Neurology. 2014;83(3):278-286.

17. Polman CH, Reingold SC, Banwell B, et al. Diagnostic criteria for multiple sclerosis: 2010 revisions to the McDonald criteria. Ann Neurol. 2011;69(2):292-302.

18. McDonald WI, Compston A, Edan G, et al. Recommended diagnostic criteria for multiple sclerosis: guidelines from the international panel on the diagnosis of multiple sclerosis. Ann Neurol. 2001;50(1):121-127.

19. Confavreux C, Vukusic S. Natural history of multiple sclerosis: a unifying concept. Brain. 2006;129(pt 3):606-616.

20. Kurtzke JF. Rating neurologic impairment in multiple sclerosis: an expanded disability status scale (EDSS). Neurology. 1983;33(11): $1444-1452$.

21. Freedman MS, Selchen D, Arnold DL, et al. Treatment optimization in MS: Canadian MS working group updated recommendations. Can J Neurol Sci. 2013;40(3):307-323.

22. IFNB Multiple Sclerosis Study Group. Interferon beta- $1 \mathrm{~b}$ is effective in relapsing-remitting multiple sclerosis. I. clinical results of a multicenter, randomized, double-blind, placebo-controlled trial. Neurology. 1993;43(4):655-661.

23. PRISMS Study Group. Randomised double-blind placebo-controlled study of interferon beta-1a in relapsing/remitting multiple sclerosis. Lancet. 1998;352(9139):1498-1504.

24. Jacobs LD, Cookfair DL, Rudick RA, et al. Intramuscular interferon beta-1a for disease progression in relapsing multiple sclerosis. The multiple sclerosis collaborative research group (MSCRG). Ann Neurol. 1996;39(3):285-294.

25. Calabresi PA, Kieseier BC, Arnold DL, et al. Pegylated interferon beta-1a for relapsing-remitting multiple sclerosis (ADVANCE): a randomised, phase 3, double-blind study. Lancet Neurol. 2014;13(7):657-665.

26. Johnson KP, Brooks BR, Cohen JA, et al. Copolymer 1 reduces relapse rate and improves disability in relapsing-remitting multiple sclerosis: results of a phase III multicenter, double-blind placebo-controlled trial. The copolymer 1 multiple sclerosis study group. Neurology. 1995; 45(7):1268-1276.

27. Fox RJ, Miller DH, Phillips JT, et al. Placebo-controlled phase 3 study of oral BG-12 or glatiramer in multiple sclerosis. $N$ Engl J Med. 2012;367(12):1087-1097. 
28. Gold R, Kappos L, Arnold DL, et al. Placebo-controlled phase 3 study of oral BG-12 for relapsing multiple sclerosis. $N$ Engl J Med. 2012;367(12):1098-1107.

29. Confavreux C, O'Connor P, Comi G, et al. Oral teriflunomide for patients with relapsing multiple sclerosis (TOWER): a randomised, double-blind, placebo-controlled, phase 3 trial. Lancet Neurol. 2014;13(3):247-256.

30. O'Connor P, Wolinsky JS, Confavreux C, et al. Randomized trial of oral teriflunomide for relapsing multiple sclerosis. $N$ Engl J Med. 2011;365(14):1293-1303.

31. Durelli L, Barbero P, Clerico M; INCOMIN Trial Study Group. A randomized study of two interferon-beta treatments in relapsing-remitting multiple sclerosis. Neurology. 2006;67(12):2264. author reply 2264-5.

32. Schwid SR, Panitch HS. Full results of the evidence of interferon doseresponse-European North American comparative efficacy (EVIDENCE) study: a multicenter, randomized, assessor-blinded comparison of lowdose weekly versus high-dose, high-frequency interferon beta-1a for relapsing multiple sclerosis. Clin Ther. 2007;29(9):2031-2048.

33. Mikol DD, Barkhof F, Chang P, et al. Comparison of subcutaneous interferon beta-1a with glatiramer acetate in patients with relapsing multiple sclerosis (the REbif vs glatiramer acetate in relapsing MS disease [REGARD] study): a multicentre, randomised, parallel, openlabel trial. Lancet Neurol. 2008;7(10):903-914.

34. O'Connor P, Filippi M, Arnason B, et al. 250 microg or 500 microg interferon beta- $1 \mathrm{~b}$ versus $20 \mathrm{mg}$ glatiramer acetate in relapsingremitting multiple sclerosis: a prospective, randomised, multicentre study. Lancet Neurol. 2009;8(10):889-897.

35. Vermersch P, Czlonkowska A, Grimaldi LM, et al. Teriflunomide versus subcutaneous interferon beta-1a in patients with relapsing multiple sclerosis: a randomised, controlled phase 3 trial. Mult Scler. 2014;20(6):705-716.

36. Roskell NS, Zimovetz EA, Rycroft CE, Eckert BJ, Tyas DA. Annualized relapse rate of first-line treatments for multiple sclerosis: a metaanalysis, including indirect comparisons versus fingolimod. Curr Med Res Opin. 2012;28(5):767-780.

37. Tolley K, Hutchinson M, You X, et al. A network meta-analysis of efficacy and evaluation of safety of subcutaneous pegylated interferon beta-1a versus other injectable therapies for the treatment of relapsingremitting multiple sclerosis. PLoS One. 2015;10(6):e0127960.

38. Tramacere I, Del Giovane C, Salanti G, D'Amico R, Filippini G. Immunomodulators and immunosuppressants for relapsing-remitting multiple sclerosis: a network meta-analysis. Cochrane Database Syst Rev. 2015;9:CD011381.

39. Calabresi PA, Radue EW, Goodin D, et al. Safety and efficacy of fingolimod in patients with relapsing-remitting multiple sclerosis (FREEDOMS II): a double-blind, randomised, placebo-controlled, phase 3 trial. Lancet Neurol. 2014;13(6):545-556.

40. Kappos L, Radue EW, O'Connor P, et al. A placebo-controlled trial of oral fingolimod in relapsing multiple sclerosis. $N$ Engl J Med. 2010;362(5):387-401.

41. Polman CH, O'Connor PW, Havrdova E, et al. A randomized, placebocontrolled trial of natalizumab for relapsing multiple sclerosis. $N$ Engl J Med. 2006;354(9):899-910.

42. Cohen JA, Coles AJ, Arnold DL, et al. Alemtuzumab versus interferon beta 1a as first-line treatment for patients with relapsing-remitting multiple sclerosis: a randomised controlled phase 3 trial. Lancet. 2012;380(9856):1819-1828.

43. Coles AJ, Fox E, Vladic A, et al. Alemtuzumab versus interferon beta-1a in early relapsing-remitting multiple sclerosis: post-hoc and subset analyses of clinical efficacy outcomes. Lancet Neurol. 2011;10(4):338-348.

44. Baker DP, Pepinsky RB, Brickelmaier M, et al. PEGylated interferon beta-1a: meeting an unmet medical need in the treatment of relapsing multiple sclerosis. J Interferon Cytokine Res. 2010;30(10):777-785.

45. Bhargava P, Newsome SD. An update on the evidence base for peginterferon $\beta 1$ in the treatment of relapsing-remitting multiple sclerosis. Ther Adv Neurol Disord. 2016;9(6):483-490.

46. Cocco E, Marrosu MG. Profile of PEGylated interferon beta in the treatment of relapsing-remitting multiple sclerosis. Ther Clin Risk Manag. 2015;11:759-766.
47. Howley A, Kremenchutzky M. Pegylated interferons: a nurses' review of a novel multiple sclerosis therapy. J Neurosci Nurs. 2014;46(2): 88-96.

48. Hoy SM. Peginterferon beta-1a: a review of its use in patients with relapsing-remitting multiple sclerosis. CNS Drugs. 2015;29(2):171-179.

49. Kieseier BC, Calabresi PA. PEGylation of interferon-beta-1a: a promising strategy in multiple sclerosis. CNS Drugs. 2012;26(3): 205-214.

50. Reuss R. PEGylated interferon beta-1a in the treatment of multiple sclerosis - an update. Biologics. 2013;7:131-138.

51. Nallar SC, Kalvakolanu DV. Interferons, signal transduction pathways, and the central nervous system. J Interferon Cytokine Res. 2014;34(8):559-576.

52. Severa M, Rizzo F, Giacomini E, Salvetti M, Coccia EM. IFN-beta and multiple sclerosis: cross-talking of immune cells and integration of immunoregulatory networks. Cytokine Growth Factor Rev. 2015;26(2):229-239.

53. Buzzard KA, Broadley SA, Butzkueven $\mathrm{H}$. What do effective treatments for multiple sclerosis tell us about the molecular mechanisms involved in pathogenesis? Int J Mol Sci. 2012;13(10):12665-12709.

54. Jacobs L, Johnson KP. A brief history of the use of interferons as treatment of multiple sclerosis. Arch Neurol. 1994;51(12):1245-1252.

55. Runkel L, Meier W, Pepinsky RB, et al. Structural and functional differences between glycosylated and non-glycosylated forms of human interferon-beta (IFN-beta). Pharm Res. 1998;15(4):641-649.

56. Kappos L, Kuhle J, Multanen J, et al. Factors influencing long-term outcomes in relapsing-remitting multiple sclerosis: PRISMS-15. J Neurol Neurosurg Psychiatry. 2015;86(11):1202-1207.

57. Goodin DS, Reder AT, Ebers GC, et al. Survival in MS: a randomized cohort study 21 years after the start of the pivotal IFNbeta- $1 \mathrm{~b}$ trial. Neurology. 2012;78(17):1315-1322.

58. Shirani A, Zhao Y, Karim ME, et al. Association between use of interferon beta and progression of disability in patients with relapsingremitting multiple sclerosis. JAMA. 2012;308(3):247-256.

59. Goodin DS, Reder AT, Cutter G. Treatment with interferon beta for multiple sclerosis. JAMA. 2012;308(16):1627. author reply 1627-8.

60. Greenberg BM, Balcer L, Calabresi PA, et al. Interferon beta use and disability prevention in relapsing-remitting multiple sclerosis. JAMA Neurol. 2013;70(2):248-251.

61. Derfuss T, Kappos L. Evaluating the potential benefit of interferon treatment in multiple sclerosis. JAMA. 2012;308(3):290-291.

62. Hegen H, Auer M, Deisenhammer F. Pharmacokinetic considerations in the treatment of multiple sclerosis with interferon-beta. Expert Opin Drug Metab Toxicol. 2015;11(12):1803-1819.

63. Fletcher JM, Lalor SJ, Sweeney CM, Tubridy N, Mills KH. T cells in multiple sclerosis and experimental autoimmune encephalomyelitis. Clin Exp Immunol. 2010;162(1):1-11.

64. Guo B, Chang EY, Cheng G. The type I IFN induction pathway constrains Th17-mediated autoimmune inflammation in mice. J Clin Invest. 2008;118(5):1680-1690.

65. Durelli L, Conti L, Clerico M, et al. T-helper 17 cells expand in multiple sclerosis and are inhibited by interferon-beta. Ann Neurol. 2009;65(5):499-509.

66. Zhang L, Yuan S, Cheng G, Guo B. Type I IFN promotes IL-10 production from $\mathrm{T}$ cells to suppress Th17 cells and Th17-associated autoimmune inflammation. PLoS One. 2011;6(12):e28432.

67. Kozovska ME, Hong J, Zang YC, et al. Interferon beta induces T-helper 2 immune deviation in MS. Neurology. 1999;53(8):1692-1697.

68. Ramgolam VS, Sha Y, Jin J, Zhang X, Markovic-Plese S. IFN-beta inhibits human Th17 cell differentiation. J Immunol. 2009;183(8): 5418-5427.

69. de Andres C, Aristimuno C, de Las Heras V, et al. Interferon beta-1a therapy enhances CD4+ regulatory T-cell function: an ex vivo and in vitro longitudinal study in relapsing-remitting multiple sclerosis. J Neuroimmunol. 2007;182(1-2):204-211.

70. Ramgolam VS, Sha Y, Marcus KL, et al. B cells as a therapeutic target for IFN-beta in relapsing-remitting multiple sclerosis. J Immunol. 2011;186(7):4518-4526. 
71. Rizzo F, Giacomini E, Mechelli R, et al. Interferon-beta therapy specifically reduces pathogenic memory $\mathrm{B}$ cells in multiple sclerosis patients by inducing a FAS-mediated apoptosis. Immunol Cell Biol. 2016;94(9):886-894.

72. Saraste M, Irjala H, Airas L. Expansion of CD56Bright natural killer cells in the peripheral blood of multiple sclerosis patients treated with interferon-beta. Neurol Sci. 2007;28(3):121-126.

73. Shinohara ML, Kim JH, Garcia VA, Cantor H. Engagement of the type I interferon receptor on dendritic cells inhibits T helper 17 cell development: role of intracellular osteopontin. Immunity. 2008;29(1):68-78.

74. Mirandola SR, Hallal DE, Farias AS, et al. Interferon-beta modifies the peripheral blood cell cytokine secretion in patients with multiple sclerosis. Int Immunopharmacol. 2009;9(7-8):824-830.

75. Liu Z, Pelfrey CM, Cotleur A, Lee JC, Rudick RA. Immunomodulatory effects of interferon beta-1a in multiple sclerosis. J Neuroimmunol. 2001;112(1-2):153-162.

76. Krakauer M, Sorensen P, Khademi M, Olsson T, Sellebjerg F. Increased IL-10 mRNA and IL-23 mRNA expression in multiple sclerosis: interferon-beta treatment increases IL-10 mRNA expression while reducing IL-23 mRNA expression. Mult Scler. 2008;14(5):622-630.

77. Ozenci V, Kouwenhoven M, Huang YM, et al. Multiple sclerosis: levels of interleukin-10-secreting blood mononuclear cells are low in untreated patients but augmented during interferon-beta- $1 \mathrm{~b}$ treatment. Scand J Immunol. 1999;49(5):554-561.

78. Calabresi PA, Tranquill LR, McFarland HF, Cowan EP. Cytokine gene expression in cells derived from CSF of multiple sclerosis patients. J Neuroimmunol. 1998;89(1-2):198-205.

79. Chen M, Chen G, Nie H, et al. Regulatory effects of IFN-beta on production of osteopontin and IL-17 by CD4+ T cells in MS. Eur J Immunol. 2009;39(9):2525-2536.

80. Bernal F, Elias B, Hartung HP, Kieseier BC. Regulation of matrix metalloproteinases and their inhibitors by interferon-beta: a longitudinal study in multiple sclerosis patients. Mult Scler. 2009;15(6):721-727.

81. Boz C, Ozmenoglu M, Velioglu S, et al. Matrix metalloproteinase-9 (MMP-9) and tissue inhibitor of matrix metalloproteinase (TIMP-1) in patients with relapsing-remitting multiple sclerosis treated with interferon beta. Clin Neurol Neurosurg. 2006;108(2):124-128.

82. Avolio C, Filippi M, Tortorella C, et al. Serum MMP-9/TIMP-1 and MMP-2/TIMP-2 ratios in multiple sclerosis: relationships with different magnetic resonance imaging measures of disease activity during IFN-beta-1a treatment. Mult Scler. 2005;11(4):441-446.

83. Calabresi PA, Pelfrey CM, Tranquill LR, Maloni H, McFarland HF. VLA-4 expression on peripheral blood lymphocytes is downregulated after treatment of multiple sclerosis with interferon beta. Neurology. 1997;49(4):1111-1116.

84. Muraro PA, Leist T, Bielekova B, McFarland HF. VLA-4/CD49d downregulated on primed $\mathrm{T}$ lymphocytes during interferon-beta therapy in multiple sclerosis. J Neuroimmunol. 2000;111(1-2):186-194.

85. Muraro PA, Liberati L, Bonanni L, et al. Decreased integrin gene expression in patients with MS responding to interferon-beta treatment. J Neuroimmunol. 2004;150(1-2):123-131.

86. Biernacki K, Antel JP, Blain M, Narayanan S, Arnold DL, Prat A. Interferon beta promotes nerve growth factor secretion early in the course of multiple sclerosis. Arch Neurol. 2005;62(4):563-568.

87. Caggiula M, Batocchi AP, Frisullo G, et al. Neurotrophic factors in relapsing remitting and secondary progressive multiple sclerosis patients during interferon beta therapy. Clin Immunol. 2006;118(1):77-82.

88. Lindquist S, Hassinger S, Lindquist JA, Sailer M. The balance of pro-inflammatory and trophic factors in multiple sclerosis patients: effects of acute relapse and immunomodulatory treatment. Mult Scler. 2011;17(7):851-866.

89. Li DK, Paty DW. Magnetic resonance imaging results of the PRISMS trial: a randomized, double-blind, placebo-controlled study of interferon-betala in relapsing-remitting multiple sclerosis. prevention of relapses and disability by interferon-betala subcutaneously in multiple sclerosis. Ann Neurol. 1999;46(2):197-206.
90. PRISMS Study Group. PRISMS-4: long-term efficacy of interferon-beta-1a in relapsing MS. Neurology. 2001;56(12):1628-1636.

91. Uitdehaag B, Constantinescu C, Cornelisse $\mathrm{P}$, et al. Impact of exposure to interferon beta-1a on outcomes in patients with relapsing-remitting multiple sclerosis: exploratory analyses from the PRISMS long-term follow-up study. Ther Adv Neurol Disord. 2011;4(1):3-14.

92. Gold R, Rieckmann P, Chang P, Abdalla J; PRISMS Study Group. The long-term safety and tolerability of high-dose interferon beta-1a in relapsing-remitting multiple sclerosis: 4-year data from the PRISMS study. Eur J Neurol. 2005;12(8):649-656.

93. Siegert RJ, Abernethy DA. Depression in multiple sclerosis: a review. J Neurol Neurosurg Psychiatry. 2005;76(4):469-475.

94. Patten SB, Francis G, Metz LM, Lopez-Bresnahan M, Chang P, Curtin F. The relationship between depression and interferon beta-1a therapy in patients with multiple sclerosis. Mult Scler. 2005;11(2):175-181.

95. Schippling S, O’Connor P, Knappertz V, et al. Incidence and course of depression in multiple sclerosis in the multinational BEYOND trial. J Neurol. 2016;263(7):1418-1426.

96. Bertolotto A, Malucchi S, Sala A, et al. Differential effects of three interferon betas on neutralising antibodies in patients with multiple sclerosis: a follow up study in an independent laboratory. $J$ Neurol Neurosurg Psychiatry. 2002;73(2):148-153.

97. Boz C, Oger J, Gibbs E, Grossberg SE; Neurologists of the UBC MS Clinic. Reduced effectiveness of long-term interferon-beta treatment on relapses in neutralizing antibody-positive multiple sclerosis patients: a Canadian multiple sclerosis clinic-based study. Mult Scler. 2007;13(9):1127-1137.

98. Hegen H, Schleiser M, Gneiss C, et al. Persistency of neutralizing antibodies depends on titer and interferon-beta preparation. Mult Scler. 2012;18(5):610-615.

99. Pachner AR, Cadavid D, Wolansky L, Skurnick J. Effect of antiIFN $\{$ beta $\}$ antibodies on MRI lesions of MS patients in the BECOME study. Neurology. 2009;73(18):1485-1492.

100. Pachner AR, Warth JD, Pace A, Goelz S; INSIGHT investigators. Effect of neutralizing antibodies on biomarker responses to interferon beta: the INSIGHT study. Neurology. 2009;73(18):1493-1500.

101. Paolicelli D, D’Onghia M, Pellegrini F, et al. The impact of neutralizing antibodies on the risk of disease worsening in interferon beta-treated relapsing multiple sclerosis: a 5 year post-marketing study. J Neurol. 2013;260(6):1562-1568.

102. Francis GS, Rice GP, Alsop JC, PRISMS Study Group. Interferon beta1a in MS: results following development of neutralizing antibodies in PRISMS. Neurology. 2005;65(1):48-55.

103. Petkau AJ, White RA, Ebers GC, et al. Longitudinal analyses of the effects of neutralizing antibodies on interferon beta-1b in relapsingremitting multiple sclerosis. Mult Scler. 2004;10(2):126-138.

104. Reynolds MW, Stephen R, Seaman C, Rajagopalan K. Persistence and adherence to disease modifying drugs among patients with multiple sclerosis. Curr Med Res Opin. 2010;26(3):663-674.

105. Steinberg SC, Faris RJ, Chang CF, Chan A, Tankersley MA. Impact of adherence to interferons in the treatment of multiple sclerosis: a non-experimental, retrospective, cohort study. Clin Drug Investig. 2010;30(2):89-100.

106. Tan H, Cai Q, Agarwal S, Stephenson JJ, Kamat S. Impact of adherence to disease-modifying therapies on clinical and economic outcomes among patients with multiple sclerosis. Adv Ther. 2011;28(1): 51-61.

107. Wong J, Gomes T, Mamdani M, Manno M, O’Connor PW. Adherence to multiple sclerosis disease-modifying therapies in Ontario is low Can J Neurol Sci. 2011;38(3):429-433.

108. Evans C, Marrie RA, Zhu F, et al. Adherence and persistence to drug therapies for multiple sclerosis: a population-based study. Mult Scler Relat Disord. 2016;8:78-85.

109. Lafata JE, Cerghet M, Dobie E, et al. Measuring adherence and persistence to disease-modifying agents among patients with relapsing remitting multiple sclerosis. J Am Pharm Assoc (2003). 2008;48(6): $752-757$. 
110. Hansen K, Schussel K, Kieble M, et al. Adherence to disease modifying drugs among patients with multiple sclerosis in Germany: a retrospective cohort study. PLoS One. 2015;10(7):e0133279.

111. Giovannoni G, Southam E, Waubant E. Systematic review of diseasemodifying therapies to assess unmet needs in multiple sclerosis: tolerability and adherence. Mult Scler. 2012;18(7):932-946.

112. Rinon A, Buch M, Holley D, Verdun E. The MS choices survey: findings of a study assessing physician and patient perspectives on living with and managing multiple sclerosis. Patient Prefer Adherence. 2011;5:629-643.

113. Treadaway K, Cutter G, Salter A, et al. Factors that influence adherence with disease-modifying therapy in MS. J Neurol. 2009;256(4): 568-576.

114. O'Rourke KE, Hutchinson M. Stopping beta-interferon therapy in multiple sclerosis: an analysis of stopping patterns. Mult Scler. 2005; 11(1):46-50.

115. Tremlett HL, Oger J. Interrupted therapy: stopping and switching of the beta-interferons prescribed for MS. Neurology. 2003;61(4):551-554.

116. Girouard N, Theoret G. Management strategies for improving the tolerability of interferons in the treatment of multiple sclerosis. Can J Neurosci Nurs. 2008;30(4):18-25.

117. Bayas A. Improving adherence to injectable disease-modifying drugs in multiple sclerosis. Expert Opin Drug Deliv. 2013;10(3): 285-287.

118. Fishburn CS. The pharmacology of PEGylation: balancing PD with PK to generate novel therapeutics. J Pharm Sci. 2008;97(10):4167-4183.

119. Turecek PL, Bossard MJ, Schoetens F, Ivens IA. PEGylation of biopharmaceuticals: a review of chemistry and nonclinical safety information of approved drugs. J Pharm Sci. 2016;105(2): 460-475.

120. Aghemo A, Rumi MG, Colombo M. Pegylated interferons alpha2a and alpha2b in the treatment of chronic hepatitis C. Nat Rev Gastroenterol Hepatol. 2010;7(9):485-494.

121. Hu X, Miller L, Richman S, et al. A novel PEGylated interferon beta1a for multiple sclerosis: safety, pharmacology, and biology. J Clin Pharmacol. 2012;52(6):798-808.

122. Kieseier BC, Arnold DL, Balcer LJ, et al. Peginterferon beta-1a in multiple sclerosis: 2-year results from ADVANCE. Mult Scler. 2015;21(8):1025-1035.
123. Arnold DL, Calabresi PA, Kieseier BC, et al. Effect of peginterferon beta-1a on MRI measures and achieving no evidence of disease activity: results from a randomized controlled trial in relapsing-remitting multiple sclerosis. BMC Neurol. 2014;14:240.

124. Newsome SD, Kieseier BC, Arnold DL, et al. Subgroup and sensitivity analyses of annualized relapse rate over 2 years in the ADVANCE trial of peginterferon beta-1a in patients with relapsing-remitting multiple sclerosis. J Neurol. 2016;263(9):1778-1787.

125. Kremenchutzky M, Liu S, Cui Y, Hung S, Seddighzadeh A, Evilevitch V. Long-term safety and tolerability of peginterferon beta-1a: interim analysis from ATTAIN, a phase 3 extension study. Neurology. 2015; 84(14):S4.002.

126. White JT, Newsome SD, Kieseier BC, et al. Incidence, characterization, and clinical impact analysis of peginterferon betala immunogenicity in patients with multiple sclerosis in the ADVANCE trial. Ther Adv Neurol Disord. 2016;9(4):239-249.

127. Halper J, Centonze D, Newsome SD, et al. Management strategies for flu-like symptoms and injection-site reactions associated with peginterferon beta-1a: obtaining recommendations using the delphi technique. Int J MS Care. 2016;18(4):211-218.

128. Hu X, Shang S, Nestorov I, et al. COMPARE: pharmacokinetic profiles of subcutaneous peginterferon beta- $1 \mathrm{a}$ and subcutaneous interferon beta-1a over 2 weeks in healthy subjects. Br J Clin Pharmacol. 2016;82(2):380-388.

129. Hernandez L, Guo S, Kinter E, Fay M. Cost-effectiveness analysis of peginterferon beta-1 a compared with interferon beta-1a and glatiramer acetate in the treatment of relapsing-remitting multiple sclerosis in the united states. J Med Econ. 2016;19(7):684-695.

130. Mori F, Kusayanagi H, Buttari F, et al. Early treatment with high-dose interferon beta-1 a reverses cognitive and cortical plasticity deficits in multiple sclerosis. Funct Neurol. 2012;27(3):163-168.

131. Patti F, Morra VB, Amato MP, et al. Subcutaneous interferon beta-1a may protect against cognitive impairment in patients with relapsingremitting multiple sclerosis: 5-year follow-up of the COGIMUS study. PLoS One. 2013;8(8):e74111.

132. Cinar BP, Kosehasanogullari G, Yigit P, Ozakbas S. Cognitive dysfunction in patients with multiple sclerosis treated with first-line disease-modifying therapy: a multi-center, controlled study using the BICAMS battery. Neurol Sci. Epub 2016 Nov 24.
Degenerative Neurological and Neuromuscular Disease

\section{Publish your work in this journal}

Degenerative Neurological and Neuromuscular Disease is an international, peer-reviewed, open access journal focusing on research into degenerative neurological and neuromuscular disease, identification of therapeutic targets and the optimal use of preventative and integrated treatment interventions to achieve improved outcomes, enhanced

\section{Dovepress}

survival and quality of life for the patient. The manuscript management system is completely online and includes a very quick and fair peer-review system. Visit http://www.dovepress.com/testimonials.php to read real quotes from published authors. 